Volume 13, Nomor 2, November 2021, pp 269-282 Copyright (C) 2017

Jurnal Akuntansi, Program Studi Akuntansi, Fakultas Bisnis,

Universitas Kristen Maranatha. ISSN 2085-8698 | e-ISSN 2598-4977.

http://journal.maranatha.edu

\title{
Ketaatan Wajib Pajak Orang Pribadi Dalam Melaporkan SPT Tahunan: Beserta Faktor-Faktor yang Mempengaruhinya
}

\author{
Muhamad Sirojudin ${ }^{1}$ \\ Program Studi S1 Akuntansi, Fakultas Ekonomi dan Bisnis, \\ Universitas Muhammadiyah Tangerang \\ muhamadsirojudin2295@gmail.com \\ Mokhammad Ihsanuddin ${ }^{2}$ \\ Program Studi S1 Akuntansi, Fakultas Ekonomi dan Bisnis, \\ Universitas Muhammadiyah Tangerang \\ ikhsanjudas08@gmail.com \\ Eni Nuraeni ${ }^{3}$ \\ Program Studi S1 Akuntansi, Fakultas Ekonomi dan Bisnis, \\ Universitas Muhammadiyah Tangerang \\ nuraenieni839@gmail.com \\ Dirvi Surya Abbas ${ }^{4}$ \\ Program Studi S1 Akuntansi, Fakultas Ekonomi dan Bisnis, \\ Universitas Muhammadiyah Tangerang \\ Abbas.dirvi@gmail.com
}

\begin{abstract}
This study examines the effect of understanding tax regulations, service quality, taxation, tax obligations, and application of e-filling on individual taxpayer compliance at KPP Pratama Kosambi. The dependent variable in this study is individual taxpayer compliance, and the independent variables in this study are understanding of tax regulations, service quality, tax sanction, willingness to pay taxes, and the application of filling. This research was conducted at KPP Pratama Kosambi Tax Service in the Tangerang area. The number of respondents in this study were 74 respondents. The sampling method in this study is incidental sampling. The result of this study conclude that the understanding of tax regulations has a negative and significant effect on taxpayer compliance. Service quality has a positive effect on individual taxpayer compliance. Tax sanctions have a positive and significant effect on individual taxpayer compliance, the desire to pay taxes has a negative and insignificant effect on individual taxpayer compliance. And the application of e-filling has no effect and is not significant on individual taxpayer compliance
\end{abstract}

Keywords: Understanding of Tax Regulations, Service Quality, Tax Sanctions, Willingness to Pay Taxes, and Implementation of e-Filling 


\begin{abstract}
Abstrak
Penelitian ini menguji pengaruh pemahaman peraturan perpajakan, kualitas pelayanan, perpajakan, kewajiban perpajakan, dan penerapan $e$-filling terhadap ketaatan wajib pajak orang pribadi dalam melaporkan SPT Tahunan di KPP Pratama Kosambi. Variabel terikat dalam penelitian ini adalah ketaatan wajib pajak orang pribadi, dan variabel bebas dalam penelitian ini adalah pemahaman peraturan perpajakan, kualitas pelayanan, sanksi perpajakan, kemauan membayar pajak, dan penerapan pengisian. Penelitian ini dilakukan pada pelayanan Pajak KPP Pratama Kosambi wilayah Tangerang. Jumlah responden dalam penelitian ini adalah 74 responden. Metode pengambilan sampel dalam penelitian ini adalah incidental sampling. Analisis riset ini menggunakan Regresi Linear Berganda. Hasil penelitian ini menyimpulkan bahwa pemahaman peraturan perpajakan berpengaruh negatif dan signifikan terhadap ketaatan wajib pajak dalam melaporkan SPT. Kualitas pelayanan berpengaruh positif terhadap ketaatan wajib pajak orang pribadi dalam melaporkan SPT. Sanksi perpajakan berpengaruh positif dan signifikan terhadap ketaatan wajib pajak orang pribadi dalam melaporkan SPT, keinginan membayar pajak berpengaruh negatif dan tidak signifikan terhadap ketaatan wajib pajak orang pribadi dalam melaporkan SPT. Dan penerapan $e$-filling tidak berpengaruh dan tidak signifikan terhadap ketaatan wajib pajak orang pribadi dalam melaporkan SPT.
\end{abstract}

\title{
Kata Kunci: Pemahaman Peraturan Perpajakan, Kualitas Pelayanan, Sanksi
} Perpajakan, Kemauan Membayar Pajak, dan Penerapan e-Filling

\section{Pendahuluan}

Indonesia iadalah negara hukum, yang didasarkan dengan undang-undang dasar 1945. Sehingga masyarakat harus menaati aturan yang ada di indonesia. Pajak ialah iuran atau sumbangan wajib secara pribadi maupun badan kepada negara yang terutang yang bersifat memaksa sesuai undangundang dengan tidak mendapatkan imbalan secara langsung dan digunakan untuk keperluan negara bagi kemakmuran rakyat (UU No. 28 Tahun 2007). Pendapatan negara dalam APBN Tahun 2020 sebesar Rp. 2.233,2 triliun, pendapatan negara sebesar Rp. 1.865,7 triliun yang bersumber dari pajak, penerimaan negara sebesar Rp. 367,2 triliun yang bersumber dari bukan objek pajak dan penerimaan negara sebesar Rp. 0,5 triliun yang bersumber dari Hibah (Kemenkeu, 2020). DJP menarget ketaatan pelaporan $80 \%$, berdasarkan data yang sudah dikumpulkan oleh DJP bahwa ada 19 juta wajib pajak yang wajib melaporkan SPTnya (DJPb.Kemenkeu, 2021) namun hingga batas waktu penyampaian SPT, sudah mencapai $63 \%$ atau sekitar 11,9 juta wajib pajak yang sudah melapor SPT. Otoritas masih mencatat masih ada sekitar 741 ribu wajib pajak badan dan juga 6,3 juta wajib pajak orang pribadi yang belum menyampaikan SPT. Penurunan pelaporan pajak disebabkan wabah virus corona, dimana berlangsung penyebaran virus tersebut pada periode penyampaian SPT pada kuartal pertama tahun 2020 (Setiawan, Agus, 2020).

Wajib Pajak yang melaksanakan hak perpajakan, dan juga memenuhi semua kewajiban perpajakan disebut juga dengan ketaatan Wajib Pajak Orang Pribadi. Ketaatan WPOP dalam melaporkan SPT tahunan dipengaruhi oleh aspek-aspek eksternal ataupun internal. Kualitas Pelayanan dan Sanksi Pajak merupakan aspek eksternal yang mempengaruhi kewajiban perpajakan. Pemahaman, 
Pengetahuan, dan juga tingkat Pendidikan merupakan aspek internal atau berasal dari dalam diri wajib pajak yang mempengaruhi ketaatan wajib pajak orang pribadi (Subarkah \& Dewi, 2017).

Menurut Lovin (2014), proses dalam memahami regulasi perpajakan yang telah ada yang dilakukan oleh wajib pajak juga disebut dengan pemahaman peraturan perpajakan. wajib pajak yang tidak memahami regulasi perpajakan cenderung akan menjadi wajib pajak yang tidak taat (As'ari, 2018). Hasil penelitian Redae (2016) menunjukkan bahwa pengetahuan regulasi perpajakan mempunyai pengaruh positif terhadap ketaatan WPOP dalam melaporkan SPT tahunan. sedangkan riset Astrina \& Septiani (2019) memberikan hasil pemahaman regulasi perpajakan tidak mempunyai pengaruh terhadap ketaatan WPOP dalam melaporkan SPT tahunan.

Proses bantuan yang dilakukan oleh fiskus merupakan suatu tindakan pelayanan kepada orang lain agar terciptanya kepuasan yang dimana semua itu disebut juga dengan kualitas pelayanan. Ramadhanty \& Zulaikha (2020) dalam risetnya memberikan bukti sesungguhnya kualitas pelayanan mempunyai pengaruh positif terhadap ketaatan WPOP dalam melaporkan SPT tahunan, sedangkan riset yang diteliti oleh Saputri \& Sulistia (2019) memberikan bukti bahwa kualitas pelayanan tidak memiliki pengaruh terhadap ketaatan WPOP dalam melaporkan SPT tahunan.

Wajib Pajak yang melanggar peraturan baik sengaja ataupun kealpaannya akan diberikan suatu tindakan atau hukuman berupa sanksi pajak. Hasil penelitian As'ari, (2018) menunjukkan sesungguhnya sanksi pajak mempunyai pengaruh yang positif terhadap ketaatan WPOP dalam melaporkan SPT tahunan, sedangkan dalam riset Hendri \& Hotang, (2019), memberikan bukti sesungguhnya sanksi pajak mempunyai pengaruh negatif terhadap ketaatan WPOP dalam melaporkan SPT tahunan.

Kuatnya kemauan ataupun keinginan yang muncul dari diri wajib pajak sendiri untuk mengikuti regulasi yang ada yang ditentukan oleh undang-undang dalam membayar pajak sesuai peraturan pajak disebut juga dengan hasrat membayar pajak (Zulaikha, 2012). Hasil penelitian Purnamasari (2017) menyatakan bahwa hasrat membayar pajak mempunyai pengaruh dan signifikan terhadap ketaatan WPOP dalam melaporkan SPT tahunan, sedangkan penelitian Kamarrudin (2018) memberikan bukti bahwa hasrat atau keinginan membayar pajak pajak mempunyai pengaruh negatif terhadap Ketaatan WPOP Dalam Melaporkan SPT tahunan.

Pelaporan SPT tahunan dengan cara menggunakan sistem online serta real time melalui ASP yang dipilih oleh DJP dalam menyampaikan SPT disebut juga dengan $e$ Filing (Rahayu, 2013 dalam Nurlaela, 2017). Riset yang diteliti oleh Agustiningsih, (2016) menampilkan bukti sesungguhnya penerapan e-filling mempunyai pengaruh positif dan signifikan terhadap ketaatan WPOP dalam melaporkan SPT tahunan, sedangkan dalam risetnya, Handayani, (2016) memberikan bukti sesungguhnya penerapan e-filling tidak mempunyai pengaruh signifikan terhadap ketaatan WPOP dalam melaporkan SPT tahunan.

Penulis memilih penelitian di Kantor Pelayanan Pajak Pratama Kosambi dikarenakan sumber daya manusia untuk berwirausaha sangat besar, karena banyaknya tempat wisata didaerah tersebut. Dan berdasarkan fenomena yang terjadi terkait ketaatan WPOP dalam melaporkan SPT tahunan yang telah diuraikan dan masih terdapat hasil yang berbeda dari penelitianpenelitian terdahulu, dan penelitian ini berbeda dengan penelitian-penelitian terdahulu, karena dengan manambah satu variabel $\mathrm{X}$ yaitu hasrat membayar Pajak sebagai kebaruan temuan (novelty). Maka penulis termotivasi untuk meneliti lebih dalam mengenai sikap atau perilaku wajib pajak yang mempunyai pengaruh ketaatan wajib pajak dengan judul penelitian “ Penerapan e-filling, Pengaruh Pemahaman 
Peraturan Perpajakan, Hasrat Membayar Pajak, kualitas pelayanan, serta sanksi pajak terhadap ketaatan WPOP dalam melaporkan SPT tahunan di KPP Pratama Kosambi Tangerang"

\section{Manfaat Penelitian}

\section{Manfaat Bagi Akademisi}

Penelitian ini diharapkan dapat memberikan sumbangan pemikiran dan pengetahuan bagi para akademisi yang tertarik didunia perpajakan.

\section{Manfaat Bagi Instansi Pemerintah}

Penelitian ini diharapkan secara praktis dapat dijadikan referensi serta evaluasi bagi lembaga kantor pelayanan pajak terkait ketaatan wajib pajak orang pribadi agar tercapainya target ketaatan wajib pajak orang pribadi dengan optimal, sehingga realisasi penerimaan pajak ditahun yang akan datang mencapai target pemerintah.

\section{Kerangka Teoritis dan Hipotesis}

\section{Tinjauan Pustaka}

Teori Atribusi (Atribution Theory) menurut Fritz Heidar, mengatakan perilaku atau sikap seseorang jika diamati, apakah perilaku tersebut timbul dari aspek internal ataupun dari aspek eksternal yang ada dari diri seseorang.

Wajib Pajak yang melaksanakan hak perpajakan, dan juga memenuhi semua kewajiban perpajakan yang dimana disebut juga dengan ketaatan wajib pajak Orang Pribadi. Ketaatan WPOP dalam melaporkan SPT tahunan dipengaruhi oleh Aspek-aspek eksternal ataupun internal. Kualitas Pelayanan, dan Sanksi Pajak merupakan aspek ekternal yang mempengaruhi kewajiban perpajakan. Pemahaman, Pengetahuan, dan juga tingkat Pendidikan merupakan aspek internal atau berasal dari dalam diri wajib pajak yang mempengaruhi ketaatan wajib pajak orang pribadi (Subarkah \& Dewi, 2017).
Menurut Lovin (2014), proses dalam memahami regulasi perpajakan yang telah ada yang dilakukan oleh wajib pajak juga disebut dengan pemahaman peraturan perpajakan. Wajib pajak yang tidak memahami regulasi perpajakan cenderung akan menjadi wajib pajak yang tidak taat (As'ari, 2018).

Menurut Utama (2013), proses bantuan yang dilakukan oleh fiskus merupakan suatu tindakan pelayanan kepada orang lain agar terciptanya kepuasan yang dimana semua itu disebut juga dengan kualitas pelayanan. Kusuma (2016), mengemukakan 5 indikator kualitas pelayanan yaitu 1. Reliability (keandalan). $2 . \quad$ Responsiveness (ketanggapan). 3. Assurance (Jaminan) 4. Emphaty (Empati). 5. Tangible (Bukti Langsung).

Menurut Tjahjono sanksi pajak merupakan suatu hukuman atau tindakan yang diberikan kepada wajib pajak yang melakukan pelanggaran baik secara sengaja maupun karena kealpaannya (Mulyana, 2014). Adi (2018) mengemukakan indikator sanksi pajak, yaitu 1. Pengetahuan WPOP tentang terdapatnya sanksi pajak. 2. Perilaku WPOP terhadap sanksi pajak, 3. Sanksi pajak harus dikenakan kepada pelanggarnya tanpa toleransi.

Menurut Kamarrudin (2018) hasrat membayar pajak yaitu suatu dorongan atau keinginan diri sendiri yang dilakukan wajib pajak untuk menaati kewajiban perpajakan dalam membayar pajak. Alfiah, (2014) mengemukakan bahwa indikator hasrat membayar pajak yaitu 1. Kemauan atau keinginan dalam menyampaikan SPT, 2. Kemauan dalam mengalokasikan dana untuk membayar pajak, 3. Tingkat pengetahuan dalam membayar pajak.

Pelaporan SPT tahunan dengan cara menggunakan sistem online serta real time melalui ASP yang dipilih oleh DJP dalam menyampaikan SPT disebut juga dengan $e$ Filing (Rahayu, 2013 dalam Nurlaela, 2017). 


\section{Metode Penelitian}

\section{Jenis Penelitian}

Jenis riset ini merupakan penelitian kuantitatif dengan pendekatan survei lapangan. Kuantitatif dapat diartikan sebagai metode yang dilakukan untuk mempelajari pada populasi ataupun ilustrasi/sampel tertentu. Pengumpulan data memakai analisis data bersifat angka-angka atau statistik, dengan maksud untuk menguji hipotesis yang sudah di tetapkan. Analisis data yang digunakan yaitu analisis statistik deskriptif, uji instrumen, uji asumsi klasik, uji ketepatan model, model persamaan regresi dan uji $\mathrm{T}$.

\section{Tempat dan Waktu Penelitian}

Riset ini dilakukan di Kantor Pelayanan Pajak Pratama Kosambi. Waktu dilakukan riset bulan Maret hingga Agustus 2021.

\section{Definisi Operasional Penelitian Variabel Terikat}

Ketaatan WPOP dalam melaporkan SPT tahunan ialah dependent variable yaitu variabel yang dipengaruhi oleh variabel bebas (independen).

Ketaatan WPOP dalam melaporkan SPT tahunan merupakan suatu tindakan patuh atau taat terhadap ketertiban pembayaran dan pelaporan kewajiban perpajakan masa dan tahunan dari wajib pajak sesuai dengan ketentuan perpajakan yang berlaku (Prabandaru, 2019).

Variabel ini diukur dengan skala likert serta menggunakan 4 indikator, yakni 1 . ketaatan dalam mendaftar diri ke kantor pajak, 2. ketaatan dalam menghitung dan membayar pajak dengan benar, 3. ketaatan dalam melaporkan SPT, 4. ketaatan dalam membayar pajak tepat waktu. Skala likert dalam penelitian ini memiliki 1-5 poin, yakni poin 1 yaitu sangat tidak setuju, poin 2 yaitu tidak setuju, poin 3 yaitu kurang setuju, poin 4 yaitu setuju, poin 5 yaitu sangat setuju.

\section{Variabel Bebas (Independen)}

Variabel bebas adalah variabel yang mempengaruhi atau yang menjadi sebab perubahannya variabel terikat. Variabel independen dalam penelitian ini adalah pemahaman peraturan perpajakan, kualitas pelayanan, sanksi pajak, hasrat membayar pajak dan penerapan $e$-filling.

Pemahaman peraturan perpajakan adalah proses dimana wajib pajak mengerti, mengetahui tentang peraturan perpajakan serta menerapkannya untuk membayar pajak, melapor pajak beserta meningkatkan ketaatan wajib pajak (Hendri \& Hotang, 2019).

Kualitas pelayanan adalah suatu proses bantuan kepada orang lain dengan cara-cara tertentu yang memerlukan sensitivitas dan hubungan interpersonal agar terwujudnya kepuasan dan keberhasilan (As'ari, 2018).

Sanksi pajak adalah jaminan bahwa ketentuan peraturan perundang-undangan perpajakan atau norma perpajakan akan ditaati, dituruti, dan dipatuhi atau dengan kata lain sanksi pajak sebagai alat untuk mencegah agar wajib pajak tidak melanggar peraturan perpajakan atau norma perpajakan (Mardiasmo, 2019).

Hasrat membayar pajak adalah suatu dorongan atau keinginan diri sendiri yang dilakukan wajib pajak untuk menaati kewajiban perpajakan dalam membayar pajak (Kamarrudin, 2018).

E-Filing merupakan cara pelaporan SPT dengan sistem online dan real time dimana penyampaian dapat dilakukan melalui ASP yang ditunjuk oleh DJP sebagai perusahaan yang menerima penyampaian (rahayu dalam Nurlaela, 2017).

\section{Populasi dan Sampel}

Populasi dalam penelitian ini adalah wajib pajak yang terdaftar di KPP Pratama Kosambi. Dan sampel dalam penelitian ini adalah wajib pajak yang melaporkan SPT tahunan.

Teknik penetuan sampel menggunakan teknik sampling insidental, sampling insidental adalah teknik penentuan 
berdasarkan kebetulan, yaitu siapa saja yang secara kebetulan berjumpa dengan periset bisa digunakan sebagai ilustrasi, apabila dilihat responden yang kebetulan ditemui sesuai untuk dijadikan sumber data (Sugiyono, 2019a). Menurut Roscoe (1982) bahwa total sampel yang layak dalam riset yaitu antara 30 hingga dengan 500, apabila dalam riset hendak melaksanakan analisis dengan multivariate (korelasi atau regresi berganda), Hingga jumlah anggota ilustrasi minimum 10 kali dari total variable yang diteliti (Sugiyono, 2019a). Dan sampel dalam penelitian ini berjumlah 74 responden.

\section{Tehnik Pengumpulan Data}

Pengumpulan informasi atau data dalam riset ini memakai kuesioner yang sudah disusun. Kuesioner merupakan metode pengumpulan data atau informasi yang dilakukan dengan cara memberikan seperangkat statement atau pertanyaan tertulis kepada responden. Beberapa pernyataan diajukan kepada responden setelah itu responden diminta untuk menanggapi sesuai komentar atau pendapat responden.

\section{Uji Coba Instrumen}

Data yang digunakan dalam uji coba ini diambil dari wajib pajak yang terdaftar di KPP Pratama Kosambi. Pengambilan data menggunakan kuesioner dengan skala likert yang untuk mengukur Pemahaman Peraturan Perpajakan (X1), Kualitas Pelayanan (X2), Sanksi Pajak (X3), Hasrat Membayar Pajak (X4), Penerapan E-filling (X5) dan Ketaatan Wajib Pajak (Y). Uji Coba instrument ini dengan menyebar 30 kuesioner kepada wajib pajak di KPP Pratama Kosambi.

\section{Uji Validitas}

Instrumen ini dikatakan valid apabila bisa menanggapi secara teliti tentang variabel yang diukur. Kuesioner dikatakan valid apabila pernyataan ataupun pertanyaan pada kuesioner sanggup mengatakan sesuatu yang diukur oleh kuesioner tersebut. Uji validitas ini menggunakan uji pearson productmoment coefficient of correlation, dengan tingkat signifikansi sebesar 0,05 dengan kriteria pengujian jika Rhitung > Rtabel maka kuesioner pun dikatakan valid. Uji ini menggunakan software SPSS versi 22.

\section{Uji Reliabilitas}

Uji instrument ini dinyatakan reliabel apabila ada kesamaan data dalam waktu yang berbeda. Kuesioner dikatakan handal ataupun reliabel apabila jawaban seseorang terhadap pernyataan atau pertanyaan ialah tidak berubah-ubah. Jika hasil cronbach alpha diatas 0,06 maka data tersebut mempunyai keandalan yang tinggi (Ghozali, 2017). Uji ini menggunakan software SPSS versi 22 ..

\section{Teknik Analisis Data}

Teknik analisis data yang digunakan adalah Analisis Regresi Linear Berganda. Regresi linear berganda berfungsi agar mengetahui pengaruh antara variabel independent dengan variabel dependen, yakni: pemahaman peraturan perpajakan, kualitas pelayanan, sanksi pajak, hasrat membayar pajak, dan penerapan e-filling terhadap ketaatan wajib pajak orang pribadi di Kantor Pelayanan Pajak Pratama Kosambi. Persamaan umum regresi linear berganda yaitu:

$\mathrm{Y}=\mathrm{a}+\mathrm{b} 1 . \mathrm{x} 1+\mathrm{b} 2 \cdot \mathrm{x} 2+\mathrm{b} 3 \cdot \mathrm{x} 3+\mathrm{b} 4 \cdot \mathrm{x} 4+e$

\section{Hasil Penelitian dan Pembahasan}

Analisis statistic deskriptif yang mempunyai fungsi agar mendeskripsikan maupun memberi keterangan terhadap obyek yang diteliti melalui ilustrasi apa adanya (Sugiyono, 2019, p. 29). Statistik deskripsi ini meliputi tabel nilai minimum, nilai maksimum, nilai rata-rata (mean), standar deviasi dan jumlah penelitian. Berikut ini 
adalah hasil analisis statistik deskriptif dengan program SPSS versi 22.

Tabel. 1

Hasil Analisis Statistik Deskriptif

Descriptive Statistics

\begin{tabular}{|c|c|c|c|c|c|}
\hline & $\mathrm{N}$ & $\begin{array}{l}\text { Mini } \\
\text { mum }\end{array}$ & $\begin{array}{l}\text { Maxi } \\
\text { mum }\end{array}$ & $\begin{array}{c}\mathrm{Me} \\
\text { an }\end{array}$ & $\begin{array}{c}\text { Std. } \\
\text { Deviation }\end{array}$ \\
\hline $\mathrm{Y}$ & 74 & 6 & 30 & $\begin{array}{r}19 . \\
27\end{array}$ & 5.577 \\
\hline $\mathrm{X} 1$ & 74 & 10 & 50 & $\begin{array}{r}33 . \\
93\end{array}$ & 9.890 \\
\hline $\mathrm{X} 2$ & 74 & 10 & 45 & $\begin{array}{r}33 . \\
80\end{array}$ & 7.011 \\
\hline X3 & 74 & 10 & 25 & $\begin{array}{r}18 . \\
70\end{array}$ & 3.491 \\
\hline $\mathrm{X} 4$ & 74 & 14 & 28 & $\begin{array}{r}21 . \\
57\end{array}$ & 4.184 \\
\hline X5 & 74 & 5 & 20 & $\begin{array}{r}17 . \\
69\end{array}$ & 2.410 \\
\hline $\begin{array}{l}\text { Valid N } \\
\text { (listwise) }\end{array}$ & 74 & & & & \\
\hline
\end{tabular}

Uji Asumsi Klasik

Uji Normalitas

Tabel 2

Hasil Uji Normalitas

One-Sample Kolmogorov-Smirnov Test

\begin{tabular}{|ll|r|}
\hline & $\begin{array}{r}\text { Unstandardize } \\
\text { d Residual }\end{array}$ \\
\hline $\mathrm{N}$ & 74 \\
Normal & Mean & .0000000 \\
Parameters & Std. Deviation & 3.54262143 \\
a,b & & .064 \\
Most & Absolute & .064 \\
Extreme & Positive & -.059 \\
Differences & Negative & .064 \\
Test Statistic & $.200^{\mathrm{c}, \mathrm{d}}$ \\
Asymp. Sig. (2-tailed)
\end{tabular}

a. Test distribution is Normal.

Berdasarkan table 2 hasil uji normalitas diatas, diketahui bahwa nilai Asymp. Sig. (2tailed) sebesar 0,200 >0,05. Maka dapat dinyatakan bahwa populasi berdistribusi normal. Sehingga tidak terjadi masalah normalitas pada penelitian ini.

\section{Uji Multikolinearitas}

Tabel 3

Hasil Uji Multikolinearitas

\begin{tabular}{|l|r|c|}
\hline \multicolumn{3}{|c|}{ Coefficients $^{\mathbf{a}}$} \\
\cline { 2 - 3 } Model & \multicolumn{2}{|c|}{ Collinearity Statistics } \\
\cline { 2 - 3 } 1 (Colerance & VIF \\
X1 & .449 & \\
X2 & .453 & 2.229 \\
X3 & .913 & 1.095 \\
X4 & .910 & 1.099 \\
X5 & .915 & 1.093 \\
\hline
\end{tabular}

Berdasarkan table 3 di atas, maka dapat disimpulkan bahwa nilai Tolerance semua variabel bebas atau independent (pemahaman peraturan perpajakan, kualitas pelayanan, sanksi pajak, hasrat membayar pajak, dan penerapan e-filling) lebih besar dari 0,10 yang berarti tidak ada korelasi antara variabel independen. Angka VIF seluruh variabel independen kurang dari 10, bersumberkan angka diatas, disimpulkan bahwa tidak terjadi multikolinearitas antara variabel.

\section{Uji Heteroskedastisitas}

Tabel 4

Hasil Uji Heteroskedastisitas

\begin{tabular}{|l|r|r|}
\hline \multicolumn{3}{|c|}{ Coefficients $^{\mathbf{a}}$} \\
Model & \multicolumn{1}{c|}{$\mathrm{t}$} & \multicolumn{1}{c|}{ Sig. } \\
\hline 1 (Constant) & .666 & .508 \\
X1 & -1.780 & .080 \\
X2 & 1.179 & .243 \\
X3 & .746 & .458 \\
X4 & -.048 & .962 \\
X5 & -.087 & .931 \\
\hline
\end{tabular}

a. Dependent Variable: RES2

Berdasarkan table 4 hasil uji diatas, diketahui bahwa nilai Sig. masing-masing variabel lebih besar dari 0,05. Maka dapat 
dinyatakan bahwa tidak terjadi masalah heteroskedastisitas pada penelitian ini.

\section{Uji Kelayakan Model (Uji F)}

\section{Tabel 5}

Hasil Uji Kelayakan Model (Uji F)

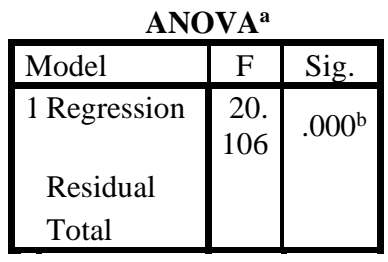

a. Dependent Variable: Y

b. Predictors: (Constant), X5,

X2, X3, X4, X1

Bersumberkan tabel 5 di atas, dapat diamati bahwa angka $F_{\text {hitung }}$ adalah 20,106. Jika membandingkan dengan $\mathrm{F}_{\text {tabel }}$ pada tingkat signifikansi $5 \%$ adalah 2,50, Hal ini berarti angka $F_{\text {hitung }}$ lebih besar dari $F_{\text {tabel }}$ $\left(\mathrm{F}_{\text {hitung }} 20,106>\mathrm{F}_{\text {tabel }} 2,50\right) \quad$ Dengan tingkat signifikansi $<0,05=0,000$ maka, dapat disimpulkan bahwa variabel pemahaman peraturan perpajakan, kualitas pelayanan, sanksi pajak dan hasrat membayar pajak secara bersama-sama berpengaruh dan signifikan terhadap ketaatan wajib pajak orang pribadi di kantor Pajak Pratama Kosambi. Dan model penelitian ini dinyatakan layak.

\section{Uji Hipotesis}

Dalam penelitian ini uji hipotesis dilakukan dengan analisis regresi linear berganda. Adapun hasil uji analisis regresi linear berganda dengan software SPSS versi 22 sebagai berikut:

\section{Tabel 6 \\ Hasil Regresi Linear Berganda}

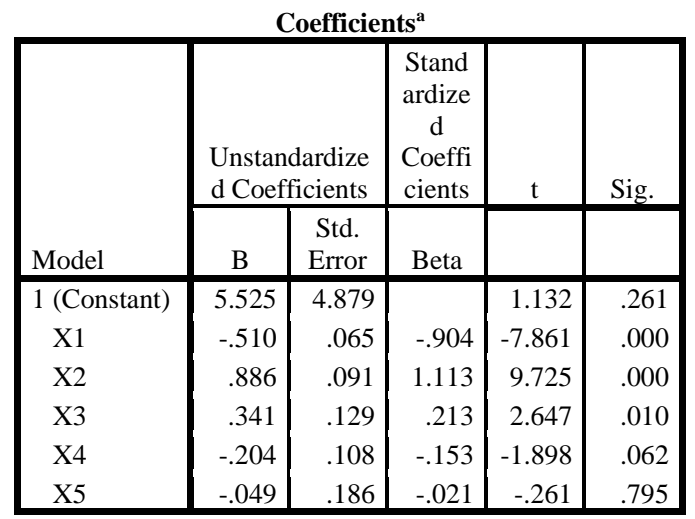

a. Dependent Variable: Y

\section{Pembahasan \\ Pengaruh Pemahaman Peraturan Perpajakan Terhadap Ketaatan Wajib Pajak Orang Pribadi di KPP Pratama Kosambi}

Berdasarkan pengujian pertama pada penelitian ini adalah untuk menguji apakah pemahaman peraturan perpajakan berpengaruh terhadap ketaatan wajib pajak orang pribadi. Berdasarkan hasil penelitian pada tabel 6 diketahui bahwa variabel X1 memiliki nilai Thitung $(-7,861)>$ nilai Ttabel $(1,667)$ dengan sig. $0,000<0,05$. Hal tersebut menunjukkan adanya pengaruh negatif signifikan yang berarti bahwa jika pemahaman peraturan perpajakan meningkat maka ketaatan wajib pajak dalam menyampaikan SPT juga akan meningkat.

Seperti penelitian yang dilakukan oleh dengan riset Dwi Anggraeni Saputri dan Ela Sulistia (2019) yang menyatakan bahwa pemahaman peraturan perpajakan mempunyai pengaruh negatif terhadap ketaatan WPOP dalam melaporkan SPT tahunan. Dimana semakin tinggi pemahaman peraturan perpajakan maka kepatuhan wajib pajak akan semakin menurun. ini diakibatkan karena, semakin tinggi pula wajib pajak mencari celah untuk tidak mematuhi peraturan perpajakan, 
berarti wajib terindikasi menghindari pajak secara legal (tax avoidance) dengan mencari celah kelemahan peraturan perpajakan.

Sehingga seiring dengan meningkatnya pengetahuan perpajakan yang dimiliki wajib pajak dapat mempengaruhi taat tidaknya wajib pajak karena wajib sudah mengetahui atas konsekuensi maupun sanksi yang bisa dikenakan jika mereka tidak melaksanakan kewajibannya dengan benar. Temuan di lapangan bahwa wajib pajak yang paham akan peraturan perpajakan mempengaruhi sikap wajib pajak dalam melaksanakan kewajiban perpajakannya. karena pemahaman pengetahuan perpajakan sangat diperlukan dalam meningkatkan ketaatan wajib pajak dapat diartikan apabila wajib pajak telah mengetahui seluruh ketentuan perpajakan yang berlaku maka wajib pajak akan dengan mudah melaksanakan kewajiban perpajakannya.

Maka dapat diinterpretasikan bahwa semakin tingginya tingkat pemahaman wajib pajak terhadap peraturan perpajakan semakin tinggi juga wajib pajak untuk mencari celah untuk tidak mematuhi peraturan perpajakan. Yang berarti wajib pajak terindikasi menghindari pajak secara legal (tax avoidance) dengan mencari celah kelemahan peraturan perpajakan. Dengan demikian semakin tingginya pemahaman wajib pajak terhadap peraturan perpajakan maka akan menurun ketaatan wajib pajak dalam menyampaikan SPT tahunan di KPP Pratama Kosambi.

\section{Pengaruh Kualitas Pelayanan Terhadap Ketaatan Wajib Pajak Orang Pribadi di KPP Pratama Kosambi.}

Pengujian kedua pada penelitian ini adalah untuk menguji apakah kualitas pelayanan berpengaruh terhadap kepatuhan wajib pajak orang pribadi. Berdasarkan tabel 6 diketahui variabel X2 memiliki nilai Thitung $(9,725)>$ Ttabel $(1,667)$ dengan nilai sig. $0,000<0,05$. Hal tersebut menunjukkan adanya pengaruh positif signifikan yang berarti bahwa jika kualitas pelayanan meningkat maka ketaatan wajib pajak dalam menyampaikan SPT akan meningkat.

Seperti riset yang dilakukan oleh Johny Subarkah, Maya Wdiyana, (2017) kualitas pelayanan mempunyai pengaruh positif terhadap ketaatan WPOP dalam melaporkan SPT tahunan. Dengan semakin baiknya pelayanan dan berkualitas pelayanan yang diberikan maka ketaatan wajib pajak akan semakin tinggi.

Adanya pelayanan yang didukung dengan fasilitas-fasilitas seperti parkir dan ruang tunggu ber- $A C$, nomor antrian elektronik, formulir-formulir pajak, tersedianya bank dalam satu area KPP sehinga memudahkan wajib pajak membayar dan melaporkan SPT dalam satu waktu. Dukungan IT atau system. Dengan adanya fasilitas-fasilitas tersebut memberikan pelayanan dengan baik, sehingga wajib pajak merasa puas dan akhirnya dapat meningkatkan ketaatan wajib pajak dalam melaksanakan kewajibannya.

Maka dapat diinterpretasikan bahwa baik buruknya pelayanan yang diberikan kepada wajib pajak akan mempengaruhi tingkat ketaatan wajib pajak orang pribadi dalam menyampaikan SPT tahunan di KPP Kosambi. Semakin baik dan berkualitas pelayanan pajak yang diberikan kepada wajib pajak akan berdampak terhadap reaksi sikap wajib pajak dalam menyampaikan SPT tahunan. Sehingga semakin tingginya kualitas pelayanan maka ketaatan wajib pajak orang pribadi dalam menyampaikan SPT tahunan akan semakin meningkat.

\section{Pengaruh Sanksi Pajak Terhadap Ketaatan Wajib Pajak Orang Pribadi di KPP Pratama Kosambi}

Pengujian ketiga pada penelitian ini adalah untuk menguji apakah sanksi pajak berpengaruh terhadap ketaatan wajib pajak orang pribadi. Berdasarkan tabel 6 bahwa variabel X3 memiliki nilai Thitung $(2,647)>$ nilai Ttabel $(1,667)$ dengan nilai sig. $0,010<$ 0,05 . Hal tersebut menunjukkan adanya pengaruh positif signifikan yang berarti 
bahwa jika sanksi pajak meningkat maka ketaatan wajib pajak juga akan meningkat.

Seperti riset yang dikerjakan Fenty Astrina \& Chessy Septiani (2019) memberikan bukti sesungguhnya sanksi pajak mempunyai pengaruh yang positif terhadap ketaatan WPOP dalam melaporkan SPT tahunan. Dengan semakin tegasnya sanksi pajak maka ketaatan wajib pajak akan meningkat. Ini diakibatkan karena ketegasan sanksi pajak yang diberikan kepada wajib pajak yang melanggar akan memberikan efek jera bagi pelanggar aturan perpajakan sehingga meningkatnya ketaatan wajib pajak dalam melaporkan SPT.

Sanksi pajak yang sudah diberikan secara tegas mampu menunjukkan peningkatan terhadap tingkat ketaatan wajib pajak orang pribadi. Sanksi yang sudah diatur yaitu sanksi administrasi, dan juga ada sanksi pidana yang meliputi denda pidana, pidana kurangan serta pidana penjara. Sanksi tersebut dapat dikenakan kepada wajib pajak yang tidak membayar pajak tepat waktu, tidak mengisi SPT secara jujur, dan tidak menyampaikan SPT tepat waktu, sehingga wajib pajak akan merasa jera atas pelanggaran yang sudah mereka lakukan.

Maka dapat diinterpretasikan bahwa semakin tingginya ketegasan sanksi pajak yang diberikan kepada wajib pajak yang melanggar dan menjadi efek jera bagi wajib pajak maka ketaatan wajib pajak juga akan meningkat, dengan kata lain sanksi pajak sebagai alat untuk mencegah agar wajib pajak tidak melanggar norma perpajakan yang ada.

\section{Pengaruh Hasrat Membayar pajak terhadap ketaatan wajib pajak orang pribadi di KPP Pratama Kosambi}

Pengujian ke empat pada penelitian ini adalah untuk menguji apakah Hasrat membayar pajak berpengaruh terhadap kepatuhan wajib pajak orang pribadi. Berdasarkan tabel 6 diketahui bahwa variabel Hasrat membayar pajak memiliki nilai $\mathrm{T}_{\text {hitung }}(-1,898)>$ Ttabel $(1,667)$ dengan nilai sig. $0,062>0,05$. Hal tersebut menunjukkan adanya pengaruh negatif tidak signifikan yang berarti jika hasrat membayar pajak meningkat maka kepatuhan wajib pajak juga akan menurun.

Seperti riset yang dilakukan oleh Kamarrudin, Evi Malia \& Imam Agus Faisol (2018) yang memberikan bukti bahwa Hasrat membayar pajak mempunyai pengaruh negative terhadap ketaatan WPOP dalam melaporkan SPT tahunan. Dengan semakin tinggi hasrat membayar pajak maka akan semakin rendah ketaatan wajib pajaknya, ini berkaitan dengan pemahaman wajib pajak terhadap peraturan perpajakan, yang dimana wajib pajak bisa mencari celah untuk mengurangi beban pajak yang dibayarkan, dengan berkurangnya beban pajak maka akan semakin tinggi pula hasrat wajib pajak untuk membayar pajak dalam artian pajak yang dibayarkan kecil, sehingga ketaatan wajib pajak menjadi rendah.

Wajib pajak yang terdaftar pada KPP Kosambi menunjukkan adanya hasrat membayar pajak yang diterapkan pada masing-masing wajib pajak sendiri. Wajib pajak sadar akan pentingnya membayar pajak sebagai penerimaan negara untuk pembangunan negara. Wajib pajak juga sadar akan akibat dari pajak yang dibayarkan semakin kecil atau tidak dibayarkan tepat waktu, yaitu salah satunya akan menghambat pembangunan negara, sehingga manfaat yang akan didapatkan oleh masyarakat akan terhambat pula.

Maka dapat interpretasikan bahwa semakin tingginya hasrat membayar pajak maka akan semakin rendah ketaatan wajib pajaknya. ini berkaitan dengan pemahaman wajib pajak terhadap peraturan perpajakan, karena wajib pajak bisa mencari celah untuk mengurangi beban pajak yang dibayarkan, dengan berkurangnya beban pajak maka akan semakin tinggi pula hasrat wajib pajak untuk membayar pajak dalam artian pajak yang dibayarkan semakin kecil, sehingga ketaatan wajib pajak menjadi menurun. 


\section{Pengaruh Penerapan e-Filling Terhadap Ketaatan Wajib Pajak Orang Pribadi di KPP Pratama Kosambi}

Pengujian kelima pada penelitian ini adalah untuk menguji apakah penerapan e-filling berpengaruh terhadap ketaatan wajib pajak orang pribadi. Berdasarkan tabel 6 bahwa variabel X4 memiliki nilai Thitung $(0,261)<$ nilai Ttabel $(1,667)$ dengan nilai sig. 0,795 > 0,05 . Hal tersebut menunjukkan tidak adanya pengaruh yang berarti bahwa jika Naik turunnya penerapan e-filling maka ketaatan wajib pajak juga tidak akan mempunyai pengaruh.

Seperti riset ini yang dilakukan oleh Handayani (2016) yang memberikan bukti sesungguhnya penerapan e-filling tidak mempunyai pengaruh signifikan terhadap ketaatan WPOP dalam melaporkan SPT tahunan. Dengan naik turunnya penerapan $e$ filling maka ketaatan wajib pajak juga tidak akan mempunyai pengaruh. Ini diakibatkan karena belum efektifnya penerapan $e$-filling serta juga wajib pajak dikabupaten belum memahami cara kerja sistem e-filling, dan sistem yang membutuhkan koneksi internet yang baik dalam menerapkan sistem $e$-filling dalam menyampaikan SPT Tahunan.

Wajib pajak orang pribadi tidak mengetahui e-filling tanpa memiliki pemahaman dan pengetahuan yang lebih mengenai perpajakan serta penerapan $e$ filling tidak akan berjalan lancar. Ketaatan wajib pajak akan mengalami peningkatan dalam melaporkan SPT tahunan jika wajib pajak memiliki pengetahuan, pemahaman serta penerapan $e$-filling.

\section{Koefisien Determinasi (Adjusted R Square)}

Tabel 7

\section{Hasil Uji Koefisien Determinasi}

\begin{tabular}{|c|c|c|c|c|}
\hline \multicolumn{5}{|c|}{ Model Summary } \\
\hline Mod & $\mathrm{R}$ & $\begin{array}{c}\mathrm{R} \\
\text { Square }\end{array}$ & $\begin{array}{l}\text { Adjusted } \\
\text { R Square }\end{array}$ & $\begin{array}{c}\text { Std. } \\
\text { Error of } \\
\text { the } \\
\text { Estimate }\end{array}$ \\
\hline 1 & $.772^{\mathrm{a}}$ & .597 & .567 & 3.671 \\
\hline
\end{tabular}

\section{a. Predictors: (Constant), X5, X2, X3, X4, X1}

Dari tampilan output SPSS versi 22 pada tabel 7 di atas besarnya Adjusted $R$ Square adalah 0,567, Hal ini mengindikasikan bahwa kontribusi variabel pemahaman peraturan perpajakan (X1), Kualitas Pelayanan (X2), Sanksi Pajak (X3), Hasrat Membayar Pajak (X4), Penerapan e-Filling (X5) sebesar 56,7\%, artinya 56,7\% variabel independen dalam riset ini mampu mejelaskan variabel dependen. sedangkan sisanya sebesar 43,3\% ditentukan oleh aspek variabel lain diluar model yang tidak terdeteksi dalam riset ini.

\section{Persamaan Regresi Linear Berganda}

Angka konstanta adalah 5,525 dan koefisien regresi Pemahaman Peraturan Perpajakan (X1) yakni -0,510, Kualitas Pelayanan (X2) yakni 0,886, Sanksi Pajak (X3) yakni 0,341, Hasrat Membayar Pajak (X4) yakni -0,204, serta Penerapan e-Filling (X5) yakni -0,049. Sehingga perolehan angka tersebut bisa dibuatkan persamaan regresi sebagai berikut:

$$
\begin{aligned}
& \mathrm{Y}=\alpha+\mathrm{b} 1 \mathrm{X} 1+\mathrm{b} 2 \mathrm{X} 2+\mathrm{b} 3 \mathrm{X} 3+\mathrm{b} 4 \mathrm{X} 4 \\
& \quad+\mathrm{b} 5 \mathrm{X} 5+\mathrm{e} \\
& \mathrm{Y}=5,525-0,510 \mathrm{X} 1+0,886 \mathrm{X} 2+0,341 \\
& \mathrm{X} 3-0,204 \mathrm{X} 4--0,049 \mathrm{X} 5+\mathrm{e}
\end{aligned}
$$

\section{Simpulan dan Saran}

Riset ini mempunyai tujuan agar mengetahui pengaruh variabel Pemahaman Peraturan Pajak, Kualitas Pelayanan, Sanksi Pajak, Hasrat Membayar Pajak serta Penerapan $e$ Filling terhadap ketaatan WPOP dalam melaporkan SPT tahunan di Kantor Pelayanan Pajak Pratama Kosambi.

Bersumberkan hasil riset yang telah dijelaskan pada sebelumnya maka dapat di tarik keputusan, sebagai berikut:

1. Pemahaman Peraturan Perpajakan mempunyai pengaruh negatif signifikan terhadap ketaatan WPOP dalam melaporkan SPT tahunan di KPP Pratama Kosambi. Maka semakin 
tingginya tingkat pemahaman wajib pajak terhadap peraturan perpajakan semakin tinggi juga wajib pajak untuk mencari celah untuk tidak mematuhi peraturan perpajakan. Yang berarti wajib pajak terindikasi menghindari pajak secara legal (tax avoidance) dengan mencari celah kelemahan peraturan perpajakan. Dengan demikian semakin tingginya pemahaman wajib pajak terhadap peraturan perpajakan maka akan menurun ketaatan wajib pajak dalam menyampaikan SPT tahunan di KPP Pratama Kosambi.

2. Kualitas Pelayanan mempunyai pengaruh positif signifikan terhadap ketaatan WPOP dalam melaporkan SPT tahunan di KPP Pratama Kosambi. Maka baik buruknya pelayanan yang diberikan ke wajib pajak akan mempengaruhi tingkat ketaatan wajib pajak orang pribadi dalam menyampaikan SPT tahunan di KPP Kosambi. Semakin baik dan berkualitas pelayanan pajak yang diberikan kepada wajib pajak akan berdampak terhadap reaksi sikap wajib pajak dalam menyampaikan SPT tahunan. Sehingga semakin tingginya kualitas pelayanan maka ketaatan wajib pajak orang pribadi dalam menyampaikan SPT tahunan akan semakin meningkat.

3. Sanksi Pajak mempunyai pengaruh positif terhadap ketaatan WPOP dalam melaporkan SPT tahunan di KPP Pratama Kosambi. Maka semakin tingginya ketegasan sanksi pajak yang diberikan kepada wajib pajak yang melanggar dan menjadi efek jera bagi wajib pajak maka ketaatan wajib pajak juga akan meningkat, dengan kata lain sanksi pajak sebagai alat untuk mencegah agar wajib pajak tidak melanggar norma perpajakan yang ada .

4. Hasrat Membayar Pajak berpengaruh negative terhadap ketaatan WPOP dalam melaporkan SPT tahunan di KPP Pratama Kosambi. Maka semakin tingginya hasrat membayar pajak maka akan semakin rendah ketaatan wajib pajaknya. ini berkaitan dengan pemahaman wajib pajak terhadap peraturan perpajakan, karena wajib pajak bisa mencari celah untuk mengurangi beban pajak yang dibayarkan, dengan berkurangnya beban pajak maka akan semakin tinggi pula hasrat wajib pajak untuk membayar pajak dalam artian pajak yang dibayarkan semakin kecil, sehingga ketaatan wajib pajak menjadi menurun.

5. Penerapan e-Filling tidak mempunyai pengaruh terhadap ketaatan WPOP dalam melaporkan SPT tahunan di KPP Kosambi. Wajib pajak orang pribadi tidak mengetahui e-filling tanpa memiliki pemahaman dan pengetahuan yang lebih mengenai perpajakan serta penerapan e-filling tidak akan berjalan lancar. Ketaatan wajib pajak akan mengalami peningkatan dalam melaporkan SPT tahunan jika wajib pajak memiliki pengetahuan, pemahaman serta penerapan $e$-filling.

\section{Saran}

Bersumberkan uraian diatas, maka dapat direkomendasi yang bermanfaat bagi riset dimasa akan datang, yakni:

1. Banyaknya WP yang belum mengetahui tentang batas waktu pembayaran pajak, cara membayar pajak, sehingga dibutuhkan sosialisasi tentang perpajakan yang berlaku saat ini, mengingat kurangnya pemahaman masyarakat mengenai perpajakan terutama yang terkait dengan tata cara perpajakan

2. Banyaknya wajib pajak yang belum sadar atau rendahnya kesadaran wajib pajak bahwa pendapatan dari pajak ialah sumber pendapatan negara yang paling besar, maka para wajib pajak akan sadar bahwa pembayaran pajak merupakan hal penting. Maka terkait hal tersebut maka perlu diadakan sosialisasi betapa 
pentingnya membayar pajak. Sosialisasi dapat dilakukan di media-media yang ada seperti televisi, instagram, youtube dan lain-lain

3. Kurangnya penggunaan sistem e-filling sehingga masih banyak wajib pajak yang menggunakan sistem manual. Maka terkait hal tersebut agar dilakukannya sosialiasi tentang sistem e-filling bagi wajib pajak di KPP Pratama Kosambi

4. Bagi peneliti selanjutnya disarankan untuk menjadikan variabel sanksi pajak sebagai variabel moderating.

\section{Daftar Pustaka}

Adi, W. T. (2018). Pengaruh Pengetahuan Perpajakan, Sanksi Pajak Dan Kesadaran Wajib Pajak Terhadap Kepatuhan Wajib Pajak Badan Pada Kpp Pratama Cilacap Tahun 2018. Skripsi. Universitas Negeri Yogyakarta.

Agustiningsih, W. (2016). Pengaruh Penerapan E-Filing, Tingkat Pemahaman Perpajakan Dan Kesadaran Wajib Pajak Terhadap Kepatuhan Wajib Pajak Di Kpp Pratama Yogyakarta. Journal Nominal, Barometer Riset Akuntansi Dan Manajemen, Vol. 5(No. 2), 107-122. Https://Doi.Org/10.21831/Nominal. V5i2.11729

Alfiah, I. (2014). Kesadaran Perpajakan, Sanksi Perpajakan, Sikap Fiskus, Lingkungan Pajak, Pengetahuan Peraturan Pajak, Persepsi Efektifitas Sistem Perpajakan, Kemauan Membayar Pajak Terhadap Kepatuhan Wajib Pajak Orang Pribadi Di Dppkad Grobogan- Purwodadi. [Universitas Muria Kudus]. Https://Doi.Org/-

As'ari, N. G. (2018). Pengaruh Pemahaman Peraturan Perpajakan, Kualitas Pelayanan, Kesadaran Wajib Pajak Dan Sanksi Pajak Terhadap Kepatuhan Wajib Pajak Orang Pribadi (Studi Empiris Pada Wajib Pajak
Orang Pribadi Kecamatan Rongkop). Jurnal Ekobis Dewantara, Vol. 1(No. 6), 64-76.

Https://Doi.Org/10.29230/Ad.V2i1.2 221

Astrina, F., \& Septiani, C. (2019). Pengaruh Pemahaman Peraturan Pajak, Sanksi Perpajakan, Pemeriksaan Pajak Terhadap Kepatuhan Wajib Pajak Orang Pribadi (Wpop). Balance: Jurnal Akuntansi Dan Bisnis, Vol. 4(No. 2), 595-606.

Https://Doi.Org/10.32502/Jab.V4i2.1 986

Djpb.Kemenkeu. (2021). Lakin Djp 2020. Https://Doi.Org/-

Ghozali, I. (2017). Ekonometrika, Teori, Konsep Dan Aplikasi Dengan Ibm Spss 24 (I. Ghozali (Ed.); 3rd Ed.). Badan Penerbit Universitas Diponegoro Semarang. Https://Doi.Org/-

Handayani, K. (2016). Pengaruh Penerapan Sistem E-Filing Dan Pengetahuan Perpajakan Terhadap Kepatuhan Wajib Pajak Dengan Sosialisasi Sebagai Variabel Moderating (Survei Pada Perkantoran Sunrise Garden Di Wilayah Kedoya, Jakarta Barat). Journal Media Akuntansi Perpajakan, Vol. 1(No. 2), 59-73. Https://Doi.Org/-

Hendri, \& Hotang, K. B. (2019). E-Filling, Pemahaman, Sanksi Perpajakan, Biaya Kepatuhan, Dan Kepuasan Kualitas Pelayanan Terhadap Kepatuhan Pelaporan Spt Tahunan Wpop. Jaaf ( Journal Of Applied Accounting And Finance ), Vol. 3(No. 2), 150-162. Https://Doi.Org/10.33021/Jaaf.V3i2. 804

Kamarrudin, D. (2018). Pengaruh Layanan Samsat Keliling, Waktu Menunggu, Hasrat Membayar Pajak Dan Persepsi Wajib Pajak Terhadap Kepatuhan Wajib Pajak Kendaraan Bermotor Di Kabupaten Pamekasan. Jurnal Seminar Nasional Ekonomi, Manajemen Dan Akuntansi (Sinema), Vol. 2(No. 1), 151160. Https://Doi.Org/2656-2952

Kemenkeu. (2020). Apbn 2020. 2020. Https://Doi.Org/-

Kusuma, C. K. (2016). Pengaruh Kualitas 
Pelayanan Pajak, Pemahaman Peraturan Perpajakan Serta Sanksi Perpajakan Terhadap Kepatuhan Wajib Pajak Orang Pribadi Dalam Membayar Pajak Tahun 2014 [Universitas Negeri Yogyakarta]. In Skripsi. Universitas Negeri Yogyakarta. Https://Doi.Org/-

Mardiasmo. (2019). Perpajakan Edisi Terbaru 2019 (D. Arum (Ed.); 2019th Ed.). Andi Yogyakarta. Https://Doi.Org/-

Mulyana, A. (2014). Sanksi Pajak Berbasis Penerimaan Negara (T. Editor (Ed.); 1st Ed.). Cv. Aneka Ilmu. Https://Doi.Org/-

Nurlaela, L. (2017). Pengaruh Penerapan EFiling Terhadap Kepatuhan Wajib Pajak Di Kpp Pratama Garut. Jurnal Wahana Akuntansi Program Studi Akuntansi S1 Dan D3 Fakultas Ekonomi, Universitas Garut, Vol. 2(No. 2), 001008. Https://Doi.Org/2527-6948

Prabandaru, A. (2019). Ketahui Indikator Kepatuhan Pajak Lewat Sistem Self Assessment. Klik Pajak. Https://Doi.Org/-

Purnamasari, D. (2017). Pengaruh Kesadaran, Persepsi Tentang Sanksi, Dan Hasrat Membayar Pajak Terhadap Kepatuhan Wajib Pajak (Studi Empiris Pada Wajib Pajak Orang Pribadi Yang Terdaftar Di Kpp Pratama Semarang Barat). Jurnal Karya Ilmiah, Vol. 1(No. 2), 150-174. Https://Doi.Org/-

Ramadhanty, A., \& Zulaikha. (2020). Pengaruh Pemahaman Tentang Perpajakan, Kualitas Pelayanan Fiskus, Sistem Transparansi Perpajakan, Kesadaran Wajib Pajak, Dan Sanksi Perpajakan Terhadap Kepatuhan Wajib Pajak Orang Pribadi. Diponegoro Journal Of Accounting, Vol. 9(No. 4), 1-12. Https://Doi.Org/-

Redae, S. (2016). Taxpayer's Knowledge And Tax Compliance Behavior In Ethiopia : A Study Of Togray State. International Journal Of Management And Commerce Innnovations, Vol. 3(No. 2), 1090-1102. Https://Doi.Org/-
Saputri, D. A., \& Sulistia, E. (2019). Pengaruh Pengetahuan Peraturan Perpajakan Dan Kualitas Pelayanan Terhadap Kepatuhan Wajib Pajak Pada Kantor Pelayanan Pajak Pratama Bandung Karees. Journal Of Accounting, Finance, Taxation, And Auditing (Jafta), Vol. 1(No. 2), 26-47. Https://Doi.Org/10.28932/Jafta.V1i2. 2453

Setiawan, Agus, D. (2020). Kepatuhan Wajib Pajak Kejar Kepatuhan Formal 80\%, Djp Imbau Wajib Pajak Tetap Lapor Spt. Ddtc News Trusted Indonesian Tax News Portal. Https://Doi.Org/-

Subarkah, J., \& Dewi, M. W. (2017). Pengaruh Pemahaman, Kesadaran, Kualitas Pelayanan, Dan Ketegasan Sanksi Terhadap Kepatuhan Wajib Pajak Orang Pribadi Di Kpp Pratama Sukoharjo. Jurnal Akuntansi Dan Pajak, Vol. 17(No. 02), 61-72. Https://Doi.Org/10.29040/Jap.V17i0 2.210

Sugiyono. (2019a). Metode Penelitian Kuantitatif, Kualitatif Dan RED (M. Dr. Ir. Sutopo. S.Pd (Ed.); 28th Ed.). Alfabeta Bandung. Https://Doi.Org/Sugiyono. (2019b). Statistika Untuk Penelitian (P. D. Sugiyono (Ed.); 30th Ed.). Penerbit Alfabeta Bandung. Www.Cvalfabeta.Com

Utama, I. (2013). Pengaruh Kualitas Pelayanan, Sanksi Perpajakan Dan Biaya Kepatuhan Terhadap Kepatuhan Wajib Pajak. E-Jurnal Akuntansi, Vol. 2(No. 2), 452-470. Https://Doi.Org/-

Zulaikha, N. (2012). Faktor-Faktor Yang Mempengaruhi Kemauan Untuk Membayar Pajak Dengan Kesadaran Membayar Pajak Sebagai Variabel Intervening (Studi Kasus Wajib Pajak Orang Pribadi Yang Melakukan Pekerjaan Bebas Yang Terdaftar Di Kpp Pratama Semarang Tengah Satu). Journal of Accounting, Finance, Taxation, And Auditing (Jafta), Vol. 1(No. 2), 1-11. Https://Doi.Org/- 